\title{
IRRESPONSIBLE BEHAVIOR OF SPANISH FTSE4GOOD IBEX COMPANIES BASED ON NGO REPORTS
}

\author{
María Dolores Espinós Vañó ${ }^{1}$, Fernando García ${ }^{2}$ \\ ${ }^{1,2}$ Faculty of Business Administration and Management, Universitat Politècnica de València, \\ Camino de Vera, s/n, 46022 València, Spain \\ E-mails: ${ }^{1}$ maesva@ade.upv.es (corresponding author); ${ }^{2}$ fergarga@esp.upv.es
}

\begin{abstract}
Recently, social responsible investment has experienced exceptional growth. For that reason, many listed companies pretend to have adopted guidelines and values proclaimed by prestigious internacional organizations as the UNO or the OECD. In fact, to adhere such guidelines is a requisite to be included in most socially responsible stock indices. In this paper we search for irresponsible behaviour by Spanish companies included in some of the world most preminent sustainable stock indices. The main result is that most of the companies have been actually critized by prestigious NGOs, so their identification as socially responsible should be questioned.
\end{abstract}

Keywords: corporate social responsibility, sustainable stock exchange indices, non-governmental organizations, ethical codes, irresponsible behaviour.

JEL Classification: G20, M14.

\section{Introduction}

The number of responsable investors has grown substantially in the last few years. As a result, the volume of assets by socially responsable investment (SRI) vehicles reached in 2016 around 22.89 billion dollars (Global Sustainable Investment Alliance, 2016). In Spain, socially responsible investment funds reached 169.359 million euros at the end of 2015, which represents $47 \%$ of the whole managed funds. However, Spain is still lagging behind neighbouring countries such as France, United Kingdon and Germany. Indeed, out of the 161 ethical investment funds available in Spain, only eight are managed by Spanish companies (Spainsif, 2016).

Although the main goal of socially responsable investors is to avoid their funds to be used in activities that are harmful to society, at the same time, investors expect to obtain a profitable return on their investments. Therefore, positive performance and investing in companies with ethical and social behavior are both goals of ethical investors (Benson, Brailsford, \& Humphrey, 2006; Berry \& Yeung, 2013).

In the case of sustainable investment funds in the Spanish market, some studies concluded that performance of socially responsible investment funds is similar to conventional funds, or may be ever higher (Albareda \& Balaguer, 2007; González Fernández \& González Velasco, 2012).
In fact, in the period from 2013 to $2016,25 \%$ of the ethical investment funds run by Spanish companies bet the performance of their benchmark indices (Spainsif, 2017).

As sustainable investment is becoming more important, an increasing number of socially responsible investors want to monitor the behavior of companies regarding social, environmental and governance (ESG) criteria (Stewart, 2003; Bird, Hall, Momente, \& Reggiani, 2007; Cheung, 2011, Adamska \& Dabrowski, 2016; Diouf, Hebb, \& Touré, 2016).

Nowadays, many international organizations are aware of the need to incorporate ethics in the companies' management as well as to inform with credibility on social management and to promote corporate social responsability (Doh \& Guay, 2006). In this line, many institutions have developed guidelines that ethical companies should follow in the environmental, social and governance areas (Carasco \& Singh, 2008).

Due to the increase in SRI, many companies have decided to voluntary adhere those guidelines and pacts proposed by prestigious international organizations, showing their commitment to respect them (Therien \& Pouliot, 2006; Fuenfschilling \& Truffer, 2014). This compromise is required by many ethical investment funds and ethical stock indices in order to identify a company as "socially responsible" and being eligible for the portfolio. 
Socially responsible investment funds and stock indices apply different strategies to identify those companies to include in their portfolios. However, all the methodologies apply a screening strategy, which can be positive or negative.

Positive screening mainly consists of selecting companies that have socially responsible practices and are highly ranked in the ESG criteria (Liondis, 2005). A variant of the positive screening strategy is the so called best-in-class, i.e., the best qualifying companies in terms of sustainability within a sector or geographical area.

Negative screening implies excluding those companies wich conduct harmful activities linked to a specific industry, such as production of weapons, nuclear energy, tobacco, alcohol, pornography, gambling etc. (Hill, Ainscough, Shank, \& Manullang, 2007). Another common exclusion criterion is non adhering to those pacts or guidelines proposed by international agencies. In fact, adherence to such guidelines is in many cases an essential requirement for a company to be considered as socially responsible and to be included in the portfolio of ethical funds and indices.

Along with the approaches described above, it is usual to find methodologies that apply various types of screening at the same time. In general, sustainable investment funds and ethical stock indices make a first selection of the assets on the basis of negative screening and subsequently apply positive screening.

The objective of this research is to assess whether Spanish ethical companies as defined by conventional screening methodologies are considered ethical or sustainable by prestigious NGOs. To this end, reports of selected NGOs have been studied to detect irresponsible behaviour by companies.

This paper is based on a new and simple methodology for carrying out negative screening, which is performed on the basis of the negative opinions and complaints published by some of the most prestigious non-governmental organizations (NGOs) in Spain and worldwide. In this line, those companies which have been blamed for non complying with national or international legislations in the fields of human rights, labour rights, the environment and taxation are identified as non ethical companies. Furthermore, companies that are involved in financing or manufacturing weapons cannot be defined as socially responsible, either. This methodology is very simple, easy to apply and therefore, very transparent. Obviously, those companies that do not comply with this fil- ter should not be able to be selected by ethical investment funds nor belong to ethical or sustainable stock indices.

The proposed methodology is applied to the companies that belong to the Spanish ethical index FTSE4Good Ibex35, which, a priori, are expected to perform a socially responsible behaviour.

\section{Social and responsible investment}

One important aspect to consider when analysing the phenomenon of socially responsible investment is that there are not official rules nor regulations that accurately define what is a socially responsible or ethical company. This lack of definition is a problem, as for any socially responsible investment fund and ethical stock index identifying those companies is the very first step. Although there is no uniform definition of what should be understood as sustainable enterprise, many funds and indices consider that in order to obtain this recognition it is a requisite to adhere the pacts and guidelines issued by international organizations (Doh \& Teegen, 2002) and compliance with the guidelines is being linked to the selection procedures of investment funds. Therefore, public companies increasingly regard these voluntary codes and the associated monitoring infrastructure as a way to attract investors.

As a result, there are many international organizations involved in the promotion of corporate social responsibility CSR. The most successful one is probably the United Nations (UN), which issued the Global Compact (UN Global Compact, 2000). The UN proposes ten fundamental principles for ethical and sustainable companies, in the areas of human rights, labour, environment and the fight against corruption (Baccaro \& Mele, 2011).

Most assessing institutions consider that those companies engaging with ethical pacts, especially to the Global Compact, should be identified as sustainable firms. As a consequence, guidelines issued by international organizations have become de facto one of the main benchmarks of CSR. Nevertheless, participating corporations just have to voluntary register and communicate their progress implementing the guidelines (Tirole \& Bénabou, 2010). But in most cases there is no accountability mechanism, and the role of the international bodies issuing the guidelines simply consists on making public the communication on progress that companies produce. Therefore, 
many NGO's claim that this kind of iniciatives allow firms to promote their socially responsible image through their association with international institutions. In fact, there is no evidence that mere participation in this kind of voluntary programmes improves corporate behaviour (Baccaro \& Mele, 2011; Windolph, 2011).

All listed responsible companies struggle very hard to communicate their social activities (Scalet \& Kelly, 2010; Robinson, Kleffner, \& Bertels, 2011; Searcy \& Elkhawas, 2012). As a result, companies issue reports which provide stakeholders information different to the purely financial and accounting reports (Brammer \& Pavelin, 2008; Bénabou and Tirole, 2009). These new models of reporting are produced with the purpose of analysing and evaluating ethical companies with both SRI and financial criteria.

The Global Reporting Initiative (GRI) created in 1997 is nowadays the most recognized international organization issuing sustainability reporting standards. The GRI standards enable companies to report on their economic, environmental and social impacts highlighting their strengths and weaknesses, showing the areas to be improved. In this regard, Spain is one of the leading countries in the submission of the so called inclusive reports (Global Reporting Initiative, 2011).

One of the most efficient tool companies have for transmiting its ethical commitment is to be listed in sustainable indices and in sustainability rankings published by international agencies (Kutay \& Tektufekçi, 2017; Tükenmez \& Gençyurek, 2017). This is why inclusion in sustainable indices has become so important for listed companies. Some publications, such as "The Most Ethical Companies in the World" by The Ethispere Institute influencesbillions of dollars in socially responsible investment (Chatterji, Levine, \& Toffel, 2009).

\section{International agencies and definition of sustainable business}

As stated above, international organizations have played a key role fostering corporate social responsibility by issuing global corporate codes of conduct. Among these agencies, the most prestigious ones are the United Nations (UN), the Organization for Economic Cooperation and Development (OECD) and the International Labour Organization (ILO).

Furthermore, there are other CSR standards or norms available, which will not be employed in this research, that can guide enterprises on how to run their business in a socially responsible and ethical way. Some of the most impotant ones are the standard ISO 26000 by the International Organization for Standardization (2014), the standard SA 8000 by the Social Accountability International, or the AA1000 series of standards by the NGO AccountAbility.

\section{UN Global Compact}

Among all the guidelines on CSR, the most influential one is the 10 principles by the UN Global Compact, which focus on human rights, labour, environment and anti-corruption measures. The ten principles are following (UN Global Compact, 2000:

1. Businesses should support and respect the protection of internationally proclaimed human rights.

2. Businesses should make sure that they are not complicit in human rights abuses.

3. Businesses should uphold the freedom of association and the effective recognition of the right of collective bargaining.

4. Businesses should support the elimination of all forms of forced and compulsory labour.

5. Businesses should support the effective abolition of child labour.

6. Businesses should support the elimination of discrimination in respect to employment and occupation.

7. Businesses should support a precautionary approach to environmental challenges.

8. Businesses should undertake initiatives to promote greater environmental responsibility.

9. Businesses should encourage the development and diffusion of environmentally friendly technologies

10. Businesses should work against corruption in all its forms, including extortion and bribery.

UN Global Compact is the world's largest corporate sustainability iniciative. Its aim is to mobilize a global movement of sustainable companies that align strategies and operations with universal principles on human rights, labour, environment and anti-corruption. Companies joining the UN Global Compact only need to fill in a questionnaire for their admission. Then, companies have two years to elaborate a report describing its compliance with the ten principles as well as their future development forecast. The number of Spanish companies adhering to the Global Compact reached 391 in 2016. Spain, despite its relative small economic size, is the country with 
the largest presence in the world in the UN Global Compact (UN Global Compact, 2017).

The protection of human rights is the most important aim of the UN Global Compact. The implementation of human rights proclaimed by the UN in 1948 (Human Rights, 1948) increased relevance for multinational companies as their geographical expansion in some cases resulted in power abuse and violation of human rights, and negligent behaviour was not always sanctioned (Ruggie, 2007). In this context, the UN Global Compact fosters the implication of multinational companies to voluntary meet fundamental responsibilities regarding human rights.

\section{OECD guidelines for multinational corporations}

The OECD launched in 2000 guidelines for multinational enterprises which main purpose is to facilitate the resolution of disputes at the enterprise level through mediation and conciliation. As multinational enterprises operate in different countries, it becomes necessary to implement uniform codes of ethical conduct, which reflect values generally accepted worldwide (OECD, 2017). The OECD guidelines for multinational enterprises are non-binding principles, whose purpose is to promote responsible business conduct in a global economy. Companies unofficially adhere to the guidelines through their representation in the Business \& Investment Advisory Committee of the OECD. Occasionally companies sign the Guidelines, although they are not intended to be endorsed by corportations (Baccaro \& Mele, 2011).

\section{The International Labour Organization's Tripartite Declaration of Principles}

In the 1960s and 1970s, the activities of multinational companies provoked intense discussions that resulted in efforts to draw up international instruments for regulating their conduct and defining the terms of their relations with host countries, mostly in the developing world. Labour-related and social policy issues were among those concerns to which the activities of multinational companies gave rise. The International Labour Organization's search for international guidelines in its sphere of competence resulted, in 1977, in the adoption of the Tripartite Declaration of Principles.

The principles offer guidelines in such areas as employment, conditions of work and life, and industrial relations. Its provisions are reinforced by certain international labour conventions and recommendations which the social partners are urged to bear in mind and apply, to the greatest extent possible.

The Tripartite Declaration of Principles was amended in 2000 and 2006 and revised in 2017 (International Labour Organization, 2017).

\section{Ethical companies and their engagement with international pacts and ethical guidelines}

As mentioned above, endorsing and adhering to guidelines issued by international institutions such as the UN, the OECD and the ILO has become a key factor for firms which want to be identified as socially responsible companies. Therefore, it is common practice that firms claim to follow the guidelines by more than one international institution.

Table 1 shows which Spanish companies included in index FTSE4Good Ibex adhere to the guidelines by the UN, the OECD and the ILO. FTSE4Good Ibex is the reference Spanish stock index for sustainable investment. The FTSE4Good Index series is designed to measure the performance of companies demonstrating strong environmental, social and governance practices. Hence, FTSE4Good indices are commonly used by investors when creating sustainable investment portfolios.

The FTSE4Good Ibex stock index components are selected among companies included in the Ibex 35 Index and the FTSE Spain All Cap indices. Selected companies must meet certain eligibility criteria regarding corporate social responsibility. The methodology used in the selection process is based on two criteria: inclusion and exclusion. All eligible companies are assessed against the FTSE4GoodIBEX inclusion criteria by the Ethical Investment Research Service and the Spanish research partner. This research is primarily based on publicly available information such as company web sites and CSR reports, with additional questionaires and company profiles sent for further clarification. Inclusion criteria are regularly revised and improved to reflect the latest trends in corporate responsibility practice. A broad range of stakholders, including investors and NGOs, help shape the criteria. The exclusion criteria exclude tobacco producers, companies manufacturing whole weapons or nuclear weapons systems and owners or operators of nuclear power stations.

Table 1 lists in alphabetical order the companies included in the FTSE4Good Ibex stock index (Madrid Stock Exchange, 2017) together with the international guidelines they adhere: UN Global 
Compact (UN), OECD Guidelines for multinational enterprises (OECD) and ILO's Tripartite Declaration of Principles (ILO).

Table 1. Spanish listed companies included in the FTSE4Good IBEX, international guidelines they adhere and inclusion in the Sustainable Yearbook 2017 by RobecoSAM

\begin{tabular}{|c|c|c|c|c|}
\hline Company & UN & OECD & ILO & YB17 \\
\hline $\begin{array}{l}\text { Abertis Infraestructu- } \\
\text { ras SA }\end{array}$ & $\mathrm{X}$ & $\mathrm{X}$ & $\mathrm{X}$ & \\
\hline Acciona SA & $\mathrm{X}$ & $\mathrm{X}$ & $X$ & $\mathrm{X}$ \\
\hline Acerinox SA & $\mathrm{X}$ & & $\mathrm{X}$ & \\
\hline $\begin{array}{l}\text { Actividades de Cons- } \\
\text { trucción y Servicio } \\
\text { SA }\end{array}$ & $X$ & & $X$ & $\mathrm{X}$ \\
\hline Aena SME.SA & $\mathrm{X}$ & & & \\
\hline $\begin{array}{l}\text { Amadeus IT Group } \\
\text { SA }\end{array}$ & $\mathrm{X}$ & & & $X$ \\
\hline Arcerlormittal SA & $\mathrm{X}$ & & & \\
\hline $\begin{array}{l}\text { Atresmedia Corpora- } \\
\text { ción de Medios de } \\
\text { Comunicación SA }\end{array}$ & $\mathrm{X}$ & & $X$ & \\
\hline Banco Sabadell SA & $\mathrm{X}$ & & & \\
\hline Banco Santander SA & $\mathrm{X}$ & $\mathrm{X}$ & $X$ & $\mathrm{X}$ \\
\hline Bankia SA & $X$ & & $X$ & $\mathrm{X}$ \\
\hline Bankinter SA & $\mathrm{X}$ & & $\mathrm{X}$ & $\mathrm{X}$ \\
\hline $\begin{array}{l}\text { Banco Bilbao Viz- } \\
\text { caya Argentaria SA }\end{array}$ & $X$ & & $\mathrm{X}$ & $\mathrm{X}$ \\
\hline $\begin{array}{l}\text { Bolsas y Mercados } \\
\text { Españoles SA }\end{array}$ & $\mathrm{X}$ & $X$ & & \\
\hline CaixaBank SA & $X$ & $X$ & $\mathrm{X}$ & \\
\hline Cellnex Telecom SA & $X$ & & $X$ & \\
\hline $\begin{array}{l}\text { Corporación Finan- } \\
\text { ciera Alba SA }\end{array}$ & $X$ & & & \\
\hline $\begin{array}{l}\text { Distribuidora Interna- } \\
\text { cional de Alimenta- } \\
\text { ción SA }\end{array}$ & $X$ & & & \\
\hline Ebro Foods SA & $\mathrm{X}$ & $X$ & $\mathrm{X}$ & \\
\hline Enagas SA & $\mathrm{X}$ & $\mathrm{X}$ & $\mathrm{X}$ & $\mathrm{X}$ \\
\hline Endesa SA & $\mathrm{X}$ & $X$ & $\mathrm{X}$ & $\mathrm{X}$ \\
\hline $\begin{array}{l}\text { Fomento de Construc- } \\
\text { ciones y Contratas SA }\end{array}$ & $X$ & $X$ & $\mathrm{X}$ & \\
\hline Ferrovial SA & $\mathrm{X}$ & $X$ & $\mathrm{X}$ & $\mathrm{X}$ \\
\hline Gas Natural SA & $X$ & $\mathrm{X}$ & $X$ & $\mathrm{X}$ \\
\hline $\begin{array}{l}\text { International Consoli- } \\
\text { dated Airlines Group }\end{array}$ & $X$ & & & \\
\hline Iberdrola SA & $X$ & & $\mathrm{X}$ & $\mathrm{X}$ \\
\hline $\begin{array}{l}\text { Industria de Diseño } \\
\text { Cia Textil SA }\end{array}$ & $X$ & $X$ & $\mathrm{X}$ & $\mathrm{X}$ \\
\hline Indra Sistemas SA & $\mathrm{X}$ & & & \\
\hline $\begin{array}{l}\text { Cia. Distribución In- } \\
\text { tegral Logista SA }\end{array}$ & $\mathrm{X}$ & & & \\
\hline Mapfre SA & $\mathrm{X}$ & $X$ & $\mathrm{X}$ & \\
\hline
\end{tabular}

End of Table 1

\begin{tabular}{|l|c|c|c|c|}
\hline \multicolumn{1}{|c|}{ Company } & UN & OECD & ILO & YB17 \\
\hline $\begin{array}{l}\text { Mediaset España Co- } \\
\text { municación SA }\end{array}$ & $\mathrm{X}$ & & & \\
\hline $\begin{array}{l}\text { Melia Hotels Interna- } \\
\text { tional SA }\end{array}$ & $\mathrm{X}$ & & & \\
\hline NH Hotel Group SA & $\mathrm{X}$ & & & \\
\hline $\begin{array}{l}\text { Obrascon Huarte Lain } \\
\text { SA }\end{array}$ & $\mathrm{X}$ & & $\mathrm{X}$ & \\
\hline $\begin{array}{l}\text { Promotora de Infor- } \\
\text { maciones SA }\end{array}$ & $\mathrm{X}$ & & & \\
\hline $\begin{array}{l}\text { Prosegur Cia. De Se- } \\
\text { guridad SA }\end{array}$ & $\mathrm{X}$ & & & \\
\hline $\begin{array}{l}\text { Red Electrica Corpo- } \\
\text { ración }\end{array}$ & $\mathrm{X}$ & & & $\mathrm{X}$ \\
\hline Repsol SA & $\mathrm{X}$ & & & $\mathrm{X}$ \\
\hline Sacyr SA & $\mathrm{X}$ & $\mathrm{X}$ & $\mathrm{X}$ & $\mathrm{X}$ \\
\hline Siemens Gamesa SA & $\mathrm{X}$ & $\mathrm{X}$ & $\mathrm{X}$ & $\mathrm{X}$ \\
\hline Telefonica SA & & & & \\
\hline
\end{tabular}

Another important benchmark and reference tool for the selection of sustainable companies is proposed by world-renowed investment specialist RobecoSAM. This company is exclusively focused on sustainability investing and is the developer of the methodology used by sustainable indices world-wide, such as the Dow Jones Sustainability Index (DJSI). Every year RobecoSAM edits the prestigious report "The Sustainable Yearbook" on the world's most sustainable companies, which analyses 3,400 invited companies from more than 40 countries. In 2017, 20 Spanish public companies were included (Table 1) in the yearbook and classified in four categories: Gold, Silver, Bronze and Industry Move. The Spanish companies in the gold category are: Enagas SA, Gas Natural SDG SA, Iberdrola SA and Industry of Textile Design SA., in the Silver are: Acciona SA, Construction Activities and Service SA, Amadeus IT Group SA, Banco de Santander SA, Ferrovial SA and Red Eléctrica Corp SA. In the bronze category we find: Endesa SA, Telefonica SA and CaixaBank SA. Finally, within the category Industry Mover, which includes $15 \%$ of the companies that have achieved the greatest improvement in sustainability compared to the previous year, the companies listed in the Spanish stock exchange are: Abertis Infraestructuras SA, Banco Bilbao Vizcaya Argentaria SA, Bankia SA, Bankinter SA, Indra SA, Siemens Gamesa SA and Repsol SA (RobecoSAM, 2017).

Looking at Table 1, it can be easily concluded that the vast majority of the big public Spanish companies are classified as ethical by 
specialized companies and follow the Global Compact guidelines and other CSR codes.

It is worth noting that all the companies mentioned in the prestigious list of RobecoSAM are included in the FTSE4Good Ibex stock index.

\section{An alternative methodology of negative screening}

Negative screening is a widely used methodology to assess the inclusion of a company in a stock index, a portfolio or a ranking. As a result, the number of companies available for investors is reduced. The aim of negative screening is to exclude those companies which perform certain producing activities, for example, nuclear weapons manufacturers. The same principle of negative screening can be applied on other activities performed by the firms. Our negative screening proposal will exclude all those companies that conduct irresponsible activities in the fields of human rights, labour rights, environment and taxation. That companies may not be defined as socially responsible, as well as those companies which are involved in the financing or production of nuclear weapons. In order to identify those irresponsible activities by corporations, reports published by prestigious NGOs are employed.

The seven NGOs selected for our study have great reputation. Some operate worldwide, while other are active only in Spain. Their work in favour of ethic and corporate social responsibility has been recognized by prestigious international organizations. The selected NGO are the following:

- International Campaign to Abolish Nuclear Weapons (ICAN): The International Campaign for the Prohibition of Nuclear Weapons was awarded the 2017 Nobel Peace Prize for its work to draw attention to the catastrophic humanitarian consequences of any use of nuclear weapons. It is a coalition of non-governmental organizations in 100 countries promoting adherence to and implementation of the UN nuclear weapon ban treatment (ICAN, 2016).

- Center for Research on Multinational Corporations (SOMO) is a critical, independent non-profit center of knowledge on multinationals, which has a broad network of 80 members in 45 countries. Since 1973, SOMO has investigated multinational corporations and the impact of their activities on people and the environment. SOMO drives analysis and pursues strategies aimed at social and sustainable change in four fields: economic justice, sustainable supply chains, natural resources and rights, remedy and accountability (SOMO, 2017).

- Greenpeace is a global, independent organization that uses peaceful protest and creative communication to expose global environmental problems and promote solutions. It was created in 1971 in Canada with the purpose of protecting and defending the environment around the world. The organization is against nuclear power and weapons. Its evolution is linked to countries with democratic systems and civil liberties. It has a powerful infrastructure with offices in more than 50 countries (Greenpeace, 2017a).

- Oxfam Intermon is a non-profit organization, whose aim is to fight for justice and peace in the world. It is part of Oxfam International, an international confederation of 22 organizations. The organization share the same goals and a rights-based approach. They develop a very important task regarding Fair Trade, creating an international trade alternative movement formed by organizations from around the world. The movement aims to change the unfair rules of international trade, which strongly contribute to global poverty and inequality (Oxfam Intermon, 2017).

- UNI Global Union: Is a non-profit organization based in Switzerland which represents more than 20 million workers from over 900 trade unions. It works together with key sustainability agencies, the UN Global Compact Leaders and forums such as the G20 and the World Economic Forum (UNI Global Union, 2017).

- Facua Consumers in Action is a domestic non-profit organization, created in Spain in 1981. It is dedicated to defending consumer rights (Facua, 2017).

- Corporate Social Responsibility Observatory (Observatorio de Responsabilidad Social Corporativa) is a domestic non-profit organization founded in Spain in 2004 by several NGOs, consumer associations and trade unions. Its goal is to foster corporate social responsibility of Spanish firms and monitor their behaviour. The Observatory carries 
out independent studies on corporate governance in Spanish public companies, based on the information reported by the companies in their financial and sustainability annual reports (Observatorio RSC).

\section{Implementation of negative screening based on the reports by NGOs about the ethical Spanish public companies}

In the following section we apply the described negative screening methodology to the list of Spanish public companies that have been identifed as socially responsible by prestigious sustainable investment specialists in section fourth of this paper. The aim of the research is to check whether those companies can still receive the label of sustainable and ethical companies after being assessed applying the simple negative screening methodology. To this end, the reports and communications issued by the NGOs mentioned in section 5 in the last years have been analysed. Those companies which the NGOs claim to performe irresponsible activitivies regarding human rights, labor rights, environment, taxation and that infringe competition and consumer protection legislation are identified. Following the proposed negative screening methodology, these companies should not be defined as sustainable or ethical companies, together with those involved in the financing of nuclear weapons and those implicated in corruption scandals.

The results of the application of the proposed screening are shown in table 2 . It is noteworthy to underline that very few companies pass the proposed screening, even though all of them are classified as socially responsible companies by prestigious sustainability investment specialists.

\section{Human rights}

Observatory CSR indicates that Repsol S.A. was requested to answer the Business \& Human Rights Resource Center to clarify information published in the media about the negative impact of the Camisea Project for the local communities in Peru (Observatorio RSC, 2015). This NGO pointed out Fomento de Construcciones y Contratas for the forced displacement of several indigenous communities in Mexico (Observatorio RSC, 2015).

Greenpeace claims MAPFRE SA for participating in a construction project in Brazil related with human rights violations (Greenpeace, 2009).

\section{Labour rights}

Regarding non-compliance with labour rights, SOMO complains that Industria de Diseño Cia. Textil SA outsources production to companies which employ children in their Bangladesh factories in almost slave labour conditions (SOMO, 2014).

Oxfam Intermon denounces that Ebro Foods SA in Morocco hires temporary employees without contracts (Oxfam Intermon, 2013).

Observatorio RSC reports that Caixabank SA hires Medical Geseme S.L. to pressure staff to control absenteeism by intimidation (Observatorio RSC, 2015).

UNI Global Union claims that Prosegur SA has repeatedly violated the OECD guidelines for multinational companies in the area of labour rights in four Latin American countries (UNI Global Union, 2014).

\section{Environment}

Regarding environmental irresponsible behaviour, many NGOs condemn the action by Spanish multinationals abroad.

Greenpeace states that Iberdrola S.A., Endesa S.A. and Gas Natural Fenosa SA are responsible for the non development of new energy sources in Spain (Greenpeace, 2017b). Greenpeace also unveiled the environmental damages by Melia and NH in the Caribbean region (Greenpeace, 2009). Finally, this NGO points out Banco Santander SA for financing deforestation in Indonesia (Greenpeace, 2015).

Oxfam Intermon complains that Ebro Foods SA has polluted the water supply in Morocco. (Oxfam Intermon, 2013).

Observatorio RSC denounced several environmental violations performed by Aena SA in Spain, Fomento de Construcciones y Contratas SA in Mexico and Repsol SA in Peru (Observatorio RSC, 2015).

\section{Taxation}

Non-compliance with taxation regulations is common practice among multinationals. Oxfam Intermon and the Observatorio RSC reported that 34 out of the 35 companies included in the Ibex-35 stock index hold 891 offshore accounts. Spanish multinationals use complex structures including trusts, foundations and shell companies to avoid or minimize the payment of taxes to the State. (Oxfam Intermon, 2015a, 2015b; Observatorio RSC, 2014). 


\section{Nuclear weapons}

As stated in the reports of the selected NGOs, Acciona SA, Banco Bilbao Vizcaya Argentaria SA, Banco de Sabadell SA and Banco Santander SA are financing or indirectly engaged in the nuclear weapons business (ICAN, 2016). It should be underlined that all these companies are included in the FTSE4Good Ibex index, whose methodology excludes companies that produce, market or finance nuclear weapons.

\section{Corruption}

Observatorio RSC exposes the participation of several multinationals in Spanish corruption scandals: Indra Sistemas S.A. (Punica file), Sacyr SA Gürtel and Barcenas files) and Fomento de Construcciones y Contratas SA (donations to political parties (Observatorio RSC, 2014).

\section{Competition}

Regarding violations of the competition regulations, FACUA denounced Telefónica SA (Facua, 2015, 2016).

Greenpeace blames Iberdrola for manipulating the Spanish energy market (Greenpeace, 2017c).

Table 2. List of Spanish companies qualified as ethical (FTSE4Good Ibex + ROBECOSAM) which perform bad practices according to the NGOs analized

\begin{tabular}{|l|l|l|}
\hline \multicolumn{1}{|c|}{ Company } & \multicolumn{1}{c|}{ ONG } & \multicolumn{1}{c|}{ Area } \\
\hline $\begin{array}{l}\text { Abertis In- } \\
\text { fraestructuras SA }\end{array}$ & $\begin{array}{l}\text { Oxfam Intermon } \\
\text { Observatorio RSC }\end{array}$ & Taxation \\
\hline Acciona SA & $\begin{array}{l}\text { Greenpeace } \\
\text { Oxfam Intermon } \\
\text { Observatorio RSC }\end{array}$ & $\begin{array}{l}\text { Taxation } \\
\text { Nuclear } \\
\text { weapons }\end{array}$ \\
\hline Acerinox SA & $\begin{array}{l}\text { Oxfam Intermon } \\
\text { Observatorio RSC }\end{array}$ & Taxation \\
\hline $\begin{array}{l}\text { Actividades de } \\
\text { Construcción y } \\
\text { Servicio SA }\end{array}$ & $\begin{array}{l}\text { Oxfam Intermon } \\
\text { Observatorio RSC }\end{array}$ & Taxation \\
\hline Aena SME.SA & Observatorio RSC & $\begin{array}{l}\text { Environ- } \\
\text { ment }\end{array}$ \\
\hline $\begin{array}{l}\text { Amadeus IT } \\
\text { Group SA }\end{array}$ & $\begin{array}{l}\text { Oxfam Intermon } \\
\text { Observatorio RSC }\end{array}$ & Taxation \\
\hline Arcerlormittal SA & Observatorio RSC & Taxation \\
\hline $\begin{array}{l}\text { Banco Sabadell } \\
\text { SA }\end{array}$ & $\begin{array}{l}\text { ICAN } \\
\text { Greenpeace } \\
\text { Oxfam Intermon } \\
\text { Observatorio RSC }\end{array}$ & $\begin{array}{l}\text { Taxation } \\
\text { wuclear } \\
\text { weapons }\end{array}$ \\
\hline $\begin{array}{l}\text { Banco Santander } \\
\text { SA }\end{array}$ & $\begin{array}{l}\text { ICAN } \\
\text { Greenpeace } \\
\text { ment } \\
\text { Taxation- }\end{array}$ \\
\hline
\end{tabular}

Continued Table 2

\begin{tabular}{|c|c|c|}
\hline Company & ONG & Area \\
\hline & $\begin{array}{l}\text { Oxfam Intermon } \\
\text { Observatorio RSC }\end{array}$ & $\begin{array}{l}\text { Nuclear } \\
\text { weapons }\end{array}$ \\
\hline Bankia SA & Observatorio RSC & Taxation \\
\hline Bankinter SA & Observatorio RSC & Taxation \\
\hline $\begin{array}{l}\text { Banco Bilbao } \\
\text { Vizcaya Argenta- } \\
\text { ria SA }\end{array}$ & $\begin{array}{l}\text { ICAN } \\
\text { Greenpeace } \\
\text { Oxfam Intermon } \\
\text { Observatorio RSC }\end{array}$ & $\begin{array}{l}\text { Taxation } \\
\text { Nuclear } \\
\text { weapons }\end{array}$ \\
\hline CaixaBank SA & $\begin{array}{l}\text { Oxfam Intermon } \\
\text { Observatorio RSC }\end{array}$ & $\begin{array}{l}\text { Labour } \\
\text { rights } \\
\text { Taxation }\end{array}$ \\
\hline $\begin{array}{l}\text { Distribuidora In- } \\
\text { ternacional de } \\
\text { Alimentación SA }\end{array}$ & $\begin{array}{l}\text { Oxfam Intermon } \\
\text { Observatorio RSC }\end{array}$ & Taxation \\
\hline Ebro Foods SA & $\begin{array}{l}\text { Oxfam Intermon } \\
\text { Observatorio RSC }\end{array}$ & $\begin{array}{l}\text { Labour } \\
\text { rights } \\
\text { Environ- } \\
\text { ment } \\
\text { Taxation }\end{array}$ \\
\hline Enagas SA & $\begin{array}{l}\text { Oxfam Intermon } \\
\text { Observatorio RSC }\end{array}$ & Taxation \\
\hline Endesa SA & $\begin{array}{l}\text { Greenpeace } \\
\text { Oxfam Intermon } \\
\text { Observatorio RSC }\end{array}$ & $\begin{array}{l}\text { Environ- } \\
\text { ment } \\
\text { Taxation }\end{array}$ \\
\hline $\begin{array}{l}\text { Fomento de } \\
\text { Construcciones y } \\
\text { Contratas SA }\end{array}$ & $\begin{array}{l}\text { Oxfam Intermon } \\
\text { Observatorio RSC }\end{array}$ & $\begin{array}{l}\text { Environ- } \\
\text { ment } \\
\text { Taxation } \\
\text { Corruption } \\
\end{array}$ \\
\hline Ferrovial SA & \begin{tabular}{|l|} 
Oxfam Intermon \\
Observatorio RSC \\
\end{tabular} & Taxation \\
\hline Gas Natural SA & $\begin{array}{l}\text { Greenpeace } \\
\text { Oxfam Intermon } \\
\text { Observatorio RSC } \\
\end{array}$ & $\begin{array}{l}\text { Environ- } \\
\text { ment } \\
\text { Taxation } \\
\end{array}$ \\
\hline $\begin{array}{l}\text { International } \\
\text { Consolidated Air- } \\
\text { lines Group }\end{array}$ & $\begin{array}{l}\text { Oxfam Intermon } \\
\text { Observatorio RSC }\end{array}$ & Taxation \\
\hline Iberdrola SA & $\begin{array}{l}\text { Greenpeace } \\
\text { Oxfam Intermon } \\
\text { Observatorio RSC }\end{array}$ & $\begin{array}{l}\text { Environ- } \\
\text { ment } \\
\text { Taxation } \\
\text { Competi- } \\
\text { tion }\end{array}$ \\
\hline $\begin{array}{l}\text { Industria de Di- } \\
\text { seño Cia Textil } \\
\text { SA }\end{array}$ & $\begin{array}{l}\text { SOMO } \\
\text { Oxfam Intermon } \\
\text { Observatorio RSC }\end{array}$ & $\begin{array}{l}\text { Human } \\
\text { rights } \\
\text { Labour } \\
\text { rights } \\
\text { Taxation }\end{array}$ \\
\hline $\begin{array}{l}\text { Indra Sistemas } \\
\text { SA }\end{array}$ & \begin{tabular}{|l|} 
Oxfam Intermon \\
Observatorio RSC \\
\end{tabular} & \begin{tabular}{|l} 
Taxation \\
Corruption \\
\end{tabular} \\
\hline Mapfre SA & $\begin{array}{l}\text { Greenpeace } \\
\text { Oxfam Intermon } \\
\text { Observatorio RSC }\end{array}$ & $\begin{array}{l}\text { Human } \\
\text { rights } \\
\text { Taxation }\end{array}$ \\
\hline
\end{tabular}


End of Table 2

\begin{tabular}{|c|c|c|}
\hline Company & ONG & Area \\
\hline $\begin{array}{l}\text { Mediaset España } \\
\text { Comunicación } \\
\text { SA }\end{array}$ & $\begin{array}{l}\text { Oxfam Intermon } \\
\text { Observatorio RSC }\end{array}$ & Taxation \\
\hline $\begin{array}{l}\text { Melia Hotels In- } \\
\text { ternational SA }\end{array}$ & $\begin{array}{l}\text { Greenpeace } \\
\text { Oxfam Intermon }\end{array}$ & $\begin{array}{l}\text { Environ- } \\
\text { ment } \\
\text { Taxation }\end{array}$ \\
\hline $\begin{array}{l}\text { NH Hotel Group } \\
\text { SA }\end{array}$ & $\begin{array}{l}\text { Greenpeace } \\
\text { Oxfam Intermon }\end{array}$ & $\begin{array}{l}\text { Environ- } \\
\text { ment } \\
\text { Taxation }\end{array}$ \\
\hline $\begin{array}{l}\text { Obrascon Huarte } \\
\text { Lain SA }\end{array}$ & $\begin{array}{l}\text { Oxfam Intermon } \\
\text { Observatorio RSC }\end{array}$ & Taxation \\
\hline $\begin{array}{l}\text { Promotora de In- } \\
\text { formaciones SA }\end{array}$ & $\begin{array}{l}\text { Oxfam Intermon } \\
\text { Observatorio RSC }\end{array}$ & Taxation \\
\hline $\begin{array}{l}\text { Prosegur Cia. De } \\
\text { Seguridad SA }\end{array}$ & $\begin{array}{l}\text { UNI Global } \\
\text { Oxfam Intermon } \\
\text { Observatorio RSC }\end{array}$ & $\begin{array}{l}\text { Labour } \\
\text { rights } \\
\text { Taxation }\end{array}$ \\
\hline $\begin{array}{l}\text { Red Electrica } \\
\text { Corporación }\end{array}$ & $\begin{array}{l}\text { Oxfam Intermon } \\
\text { Observatorio RSC }\end{array}$ & Taxation \\
\hline Repsol SA & $\begin{array}{l}\text { Greenpeace } \\
\text { Oxfam Intermon } \\
\text { Observatorio RSC }\end{array}$ & \begin{tabular}{|l} 
Human \\
rights \\
Environ- \\
ment \\
Taxation \\
\end{tabular} \\
\hline Sacyr SA & Observatorio RSC & \begin{tabular}{|l} 
Taxation \\
Corruption
\end{tabular} \\
\hline $\begin{array}{l}\text { Siemens Gamesa } \\
\text { SA }\end{array}$ & $\begin{array}{l}\text { Oxfam Intermon } \\
\text { Observatorio RSC }\end{array}$ & Taxation \\
\hline Telefonica SA & $\begin{array}{l}\text { Oxfam Intermon } \\
\text { Facua } \\
\text { Observatorio RSC }\end{array}$ & $\begin{array}{l}\text { Taxation } \\
\text { Competi- } \\
\text { tion }\end{array}$ \\
\hline
\end{tabular}

Table 2 clearly shows that most of the companies identified as sustainable and ethical companies by the Spanish sustainable index FTSE4Good Ibex and in the international investment specialist RobecoSAM have been claimed for developing not ethical or sustainable behavior by prestigious NGOs. In fact, only 5 companies out of the 41 enterprises included in the FTSE4Good Ibex index pass the assessment of the proposed negative screening, namely Atresmedia Corporación de Medios de Comunicacion SA, Bolsas y Mercados Españoles SA, Cellnex Telecom SA, Corporacion Financiera Alba SA and Cia. Distribución Integral Logista. Furthermore, no company represented in the RobecoSAM Yearbook 2017 could be declared as ethical and sustainable when applying our negative screening. It is interesting to recall that the 17 corporations in the RobecoSAM yearbook are included in the index FTSE4Good Ibex, as well.
A more detailed look at the companies which have infringed sustainable or ethical guidelines shows that 17 firms have conducted badly in one of the seven areas analysed. 13 companies conduct irresponsibe behavior in 2 areas and 6 companies in 3 areas.

As for the areas where ethical public Spanish companies behave irresponsibly according to the selected NGOs, most of the firms fail to meet ethical standards in the taxation area. That is, 35 firms out of 36. Environmetal infringement is next (10 companies). Then, we find companies engaged with nuclear weapons and being claimed for bad behavior regarding labor rights (4 companies each). There are 3 companies involved in corruption scandals, and 3 companies are blamed for infringement of human rights. Finally, 2 companies are accused of anticompetition activities which have a negative impact on cosumers.

\section{Conclusions}

The number of socially concerned investors has been growing significantly in the last decade and so the volume of assets managed by socially responsible investment vehicles. In this context, it is of great importance to identify, in a simple and transparent way, which companies can be labelled as ethical and sustainable companies. One of the most popular options is to choose those companies which adhere the guidelines and pacts of prestigious international organizations, such as the UN, the OECD or the ILO.

Another popular option to implement this selection is to pick up those companies which are included in sustainable and ethic stock indices or to select those companies included in sustainable ranking published by prestigious investment firms. Usually, investment experts apply positive and negative screening methods looking at many different indicators which have to be weighted. As a result, the methodology applied is not always transparent nor clear. Moreover, in many cases companies are defined as ethical or sustainable against common knowledge of ethical investors, who know that the companies are involved in controversies regarding environmental behaviour, corruption, taxation etc.

This paper proposes a simple and transparent negative screening methodology to identify ethical and sustainable companies. The methodology consist of analyzing the reports and websites of seven prestigious NGOs and search for irresponsible behavior of public companies. This simple selection strategy has been applied on the set of 
Spanish companies included in the Spanish sustainable stock index FTSEE4Good Ibex and in the RobeconSAM yearbook 2017. All of these companies claim to follow the guidelines by the UN Global Compact and other internationally adopted principles.

Unfortunately, the analysis shows that just 5 out of the 41 selected companies would pass our negative screening. Irresponsible behavior appears in all 7 fields analyzed: human rights, labor rights, environment, taxation, nuclear weapons, corruption and competition. This result reveals the huge differences between our simple screening methodology and those methodologies employed by investment firms. Furthermore, the impact of international pacts and guidelines on actual social and environmental performance seems to be rather scarce.

These results highlight the problem faced by ethical investors who want to identify socially responsible companies. If conventional standards cannot be trusted, the task of selecting ethical companies becomes a big burden. Maybe some additional information sources could be used, like the companies controversies by Thomson Reuters, but this is a very expensive solution.

It is important to mention that the problem described in this paper is not just regarding Spanish companies, as pointed out by several papers mentioned in the introduction.

Finally, our study should be further developed in order to include the opinions of more NGOs. Furthermore, other information sources could be used to identify irresponsibe behavior by companies, such as news in the mass media or the fines issed by courts. The selection of companies to be analysed could be made by considering those applying other CSR standards. The analysis could also be extended to companies in other countries.

\section{Disclosure statement}

Authors declare that they have no competing financial, professional, or personal interests from other parties.

\section{References}

AccountAbility. (2008). AA1000 Series of Standards. Retrieved from http://www.accountability.org/standards/

Adamska, A., \& Dabrowski, T. J. (2016). Do investors appreciate information about Corporate Social Responsibility? Evidence from the Polish equity market. Engineering Economics, 27(4), 364-372.

https://doi.org/10.5755/j01.ee.27.4.13377
Albareda, L., \& Balaguer, M. R. (2007). Análisis comparativo de la rentabilidad financiera de los fondos de inversión socialmente responsables en España. Análisis Financiero, 105, 34-44.

Baccaro, L., \& Mele, V. (2011). For lack of anything better? International organizations and global corporate codes. Public Administration, 89, 451-470.

https://doi.org/10.1111/j.1467-9299.2011.01918.x

Bénabou, R., \& Tirole, J. (2009). Individual and corporate social responsibility. IZA Discussion Papers 4570 . Retrieved from http://hdl.handle.net/10419/36339

Benson, K. L., Brailsford, T. J. Y., \& Humphrey, J. E. (2006). Do socially responsable fund managers really invest differently?. Journal of Business Ethics, 65, 337-357. https://doi.org/10.1007/s10551-006-0003-8

Berry, R. H., \& Yeung, F. (2013). Are investors willing to sacrifice cash for morality?. Journal of Business Ethics, $117,477-492$.

https://doi.org/10.1007/s10551-012-1529-6

Bird, R., Hall, D. A., Momente, F., \& Reggiani, F. (2007). What corporate social activities are valued by the market?. Journal of Business Ethics, 76(2), 189-206. https://doi.org/10.1007/s10551-006-9268-1

Brammer, S., \& Pavelin, S. (2008). Factors influencing the quality of corporate environmental disclosure. Business Strategy and the Environment, 17, 120-136. https://doi.org/10.1002/bse.506

Carasco, E. F., \& Singh, J. B. (2008). Human rights in global business ethics codes. Business and Society Review, 113, 347-374.

Chatterji, A. K., Levine, D. I., \& Toffel, M. W. (2009). How well do social ratings actually measure corporate social responsibility?. Journal of Economics \& Management Strategy, 18(1), 125-169. https://doi.org/10.1111/j.1530-9134.2009.00210.x

Cheung, A. W. K. (2011). Do stock investors value corporate sustainability?. Journal of Business Ethics, 99(2), 145165. https://doi.org/10.1007/s10551-010-0646-3

Diouf, D., Hebb, T., \& Touré, E. H. (2016). Exploring factors that influence social retail investors' decisions: evidence from Desjardins fund. Journal of Business Ethics, 134, 45-67. https://doi.org/10.1007/s10551-014-2307-4

Doh, J. P., \& Guay, R. T. (2006). Corporate social responsibility, public policy, and NGO activism in Europe and the United States: an institutional-stakeholder perspective. Journal of Management Studies, 43(1), 47-73. https://doi.org/10.1111/j.1467-6486.2006.00582.x

Doh, J. P., \& Teegen, H. (2002). Nongovernmental organizations as institutional actors in international business: theory and implications. International Business Review, 11(6), 665-684. https://doi.org/10.1016/S0969-5931(02)00044-6

Facua. (2016). Tras la denuncia de FACUA, la Junta multa a Telefónica con 6,23 millones por la subida de Movistar Fusión. Retrieved from https://www.facua.org/es/ noticia.php? Id=11020

Facua. (2015). Retrieved from https://www.facua.org/es/noticia.php? Id= 11020

Facua. (2017). Retrieved from https://www.facua.org

Fuenfschilling, L., \& Truffer, B. (2014). The structuration of socio-technical regimes - conceptual foundations from institutional theory. Research Policy, 43(4), 772-791. https://doi.org/10.1016/j.respol.2013.10.010

Global Reporting Initiative. (2011). Guia para la elaboración de Memorias de Sostenibilidad. Retrieved from 
https://www.globalreporting.org/resourcelibrary/Spanish-G3.1-Complete.pdf

Global Sustainable Investment Alliance. (2016). Global sustainable investment review. Retrieved from http://www.gsi-alliance.org/wp-content/uploads/ 2017/03/GSIR Review2016

González Fernández, M., \& González Velasco, C. (2012). ¿Difiere la rentabilidad y el riesgo en los fondos de inversión no convencionales?. Cuadernos de Economía y Dirección de la Empresa, 16 (3), 194-204. https://doi.org/10.1016/j.cede.2012.11.003

Greenpeace. (2009). Multinacionales españolas en América latina. Retrieved from http://archivo-es.greenpeace.org/espana/es/reports/100219-02/

Greenpeace. (2015). El bosque destruido del Banco de Santander. Retrieved from http://archivo-es.greenpeace.org/espana/es/Blog/el-bosque-destruido-delbanco-santander/blog/52102/

Greenpeace. (2017a). Retrieved from http://www.greenpeace.org/espana/es/

Greenpeace. (2017b). Le devolvemos la contaminación a Endesa, Iberdrola y Gas Natural Fenosa en sus sedes. Retrieved from http://archivo-es.greenpeace.org/espana/es/Blog/accin-le-devolvemos-al-contaminacin-aendesa-/blog/59071/

Greenpeace. (2017c). Greenpeace exige medidas para restringir el poder de las eléctricas y evitar casos como la denuncia de Anticorrupción a Iberdrola. Retrieved from http://archivo-es.greenpeace.org/espana/es/news/ 2017/Mayo/Greenpeace-exige-medidas-para-restringir-el-poder-de-las-electricas-y-evitar-casoscomo-la-denuncia-de-Anticorrupcion-a-Iberdrola/

Hill, R. P., Ainscough, T., Shank, T., \& Manullang, D. (2007). Corporate social responsibility and socially responsible investing: a global perspective. Journal of Business Ethics, 70, 165-174. https://doi.org/10.1007/s10551-006-9103-8

ICAN. (2016). Don't bank on the bomb. A Global Report on the financing of nuclear weapons producers.

International Labour Organization. (2001). Tripartite declaration of principles concerning multinational enterprises and social policy (MNE Declaration). Retrieved from http://www.ilo.org/empent/Publications/WCMS 094386/lang--en/index.htm

International Labour Organization. (2017). Tripartite Declaration of Principles. Retrieved from https://www. ilo.org/empent/areas/mne-declaration/lang--en/index. $\mathrm{htm}$

International Organization for Standardization. (2014). Guidance on Social Responsibility. Retrieved from https://www.iso.org/standard/42546.html

Kutay, N., \& Tektüfekçi, F. (2017). A new era for sustainable development: a comparison of sustainability indices. Journal of Accounting, Finance and Auditing Studies, 2(2), 70-95.

Lara Bueno, M. I., \& Roig Gómez, A. (2003). Panorama actual de los Fondos de Inversión Eticos y Solidarios en España. Análisis Financiero, 92, 32-43.

Liondis, G. (2005). Mainstream managers wake up to social responsibility. Money Management, 19, 15-15.

Madrid Stock Exchange (2017). Companies included in the FTSE4Good Ibex stock index. Retrieved from http://www.bolsamadrid.es/docs/SBolsas/InformesSB/ Compo4G.pdf

Observatorio de Responsabilidad Social Corporativa. (2014). La Responsabilidad Social Corporativa en las memorias anuales de las empresas del IBEX 35. Análisis: Fiscalidad del ejercicio. Retrieved from http://observatoriorsc.org/la-responsabilidad-social-corporativa-en-las-memorias-anuales-de-las-empresas-delibex-35/

Observatorio de Responsabilidad Social Corporativa. (2015). Los derechos humanos y los derechos laborales en las memorias anuales del IBEX 35. Retrieved from $\mathrm{http} / / /$ observatoriorsc.org/los-derechos-humanos-losderechos-laborales-las-memorias-anuales-del-ibex-35/

Observatorio de Responsabilidad Social Corporativa. (2017). Retrieved from http://observatoriorsc.org

OECD. (2017). Guidelines for multinational enterprises. Retrieved from http://www.oecd.org/corporate/mne/

Oxfam Intermon. (2013). El impacto social debe ser la piedra angular de la actuación de la empresa española en el exterior. Retrieved from https://www.oxfamintermon.org/es/sala-de-prensa/nota-de-prensa/impacto-social-debe-ser-piedra-angular-de-actuacion-de-empresa-espanol

Oxfam Intermon. $\left(2015^{\mathrm{a}}\right) \cdot$ ¿Beneficios para quién? Retrieved from https://www.oxfamintermon.org/es/que-hace$\mathrm{mos} / \mathrm{proyectos} /$ desigualdad/ilusion-fiscal

Oxfam Intermón. (2015b). La Ilusión Fiscal. Demasiadas sombras en la fiscalidad de las grandes empresas. Informe número 36. Retrieved from https://www.ara.cat/ 2015/03/05/1315148474.pdf

Oxfam Intermon. (2017). Retrieved from http://www.oxfamintermon.org/es/quienes-somos

RobecoSam. (2017). The Year Book 2017. Retrieved from http://yearbook.robecosam.com/methodology

Robinson, M., Kleffner, A., \& Bertels, S. (2011). Signaling sustainability leadership: empirical evidence of the value of DJSI membership. Journal of Business Ethics, 101(3), 493-505. https://doi.org/10.1007/s10551-011-0735-y

Ruggie, J. (2007). Business and human rights: the evolving international agenda, corporate social responsibility initiative, working paper 31. Cambridge: John F. Kennedy School of Government, Harvard University.

Scalet, S., \& Kelly, T. F. (2010). CSR rating agencies: what is their global impact?. Journal of Business Ethics, 94, 69-88. https://doi.org/10.1007/s10551-009-0250-6

Searcy, C., \& Elkhawas, D. (2012). Corporate sustainability ratings: an investigation into how corporations use the Dow Jones Sustainability Index. Journal of Cleaner Production, 35, 79-92. https://doi.org/10.1016/j.jclepro.2012.05.022

SOMO. (2014). Flawed fabrics. Retrieved from https://www.somo.nl/flawed-fabrics/

SOMO. (2017). Retrieved from https://www.somo.nl/aboutsomo/

Social Accountability International. (1997). SA8000 Standard. Retrieved from http://www.sa-intl.org/index.cfm? fuseaction=Page.ViewPage\&PageID=1689

Spainsif. (2016). La Inversión Socialmente Responsable en España. Retrieved from http://www.spainsif.es/wpcontent/uploads/dlm_uploads/2017/01/estudiospainsif-2016.pdf

Spainsif. (2017). Retrieved from http://www.spainsif.es/infovdos/

Stewart, L. (2003). Reputation and corporate responsibility. Journal of Communication Management, 7(4), 356366, https://doi.org/10.1108/13632540310807494

Therien, J. P., \& Pouliot, V. (2006). The Global Compact: shifting the politics of international development? Global Governance, 7(4), 499-531. 
Tirole, J., \& Bénabou, R. (2010). Individual and corporate social responsibility. FEEM Working Paper No. 23.2010. Retrieved from https://ssrn.com/abstract $=1573694$

Tükenmez, N. M., \& Gençyürek, A. G. (2017). Sustainability indices in developing countries: a study about Borsa Istambul Sustainability Index. Journal of Accounting, Finance and Auditing Studies, 2(2), 39-69.

UN Global Compact. (2017). Retrieved from https://www.unglobalcompact.org/what-is-gc

United Nations. (1948). Universal Declaration of Human Rights, Dec 10, 1948, U.N. DocA/810.
UN Global Compact. (2000). The ten principles of the UN Global Compact. Retrieved from https://www.unglobalcompact.org/what-is-gc/mission/principles

UNI Global Union. (2014). UNI global Union denuncia a Prosegur. Retrieved from https://www.facebook.com/ VigilantesdeSeguridad/posts/800392923345651

UNI Global Union. (2017). Retrieved from http://www.uniglobalunion.org/

Windolph, S. E. (2011). Assessing corporate sustainability through ratings: challenges and their causes. Journal of Environmental Sustainability, 1(1), 61-80.

https://doi.org/10.14448/jes.01.0005 